\title{
Agnieszka Kłos
}

\section{Nowe źródła zasobów własnych Unii Europejskiej}

\section{Streszczenie}

Wspólnoty Europejskie, a później Unia Europejska, miały podejmować wszelkie działania prowadzące do zmniejszenia różnic w rozwoju gospodarczym poszczególnych państw członkowskich oraz w ich regionach. Te cele były osiągane m.in. poprzez utworzenie unii celnej, jednolitego rynku europejskiego, utworzenie docelowo unii gospodarczej i walutowej oraz wprowadzanie i realizację polityki: handlowej, rolnej, spójności, konkurencji itp. Nierozłącznie z funkcjonowaniem Unii Europejskiej i urzeczywistnianiem jej celów wiąże się problem pozyskania środków finansowych, które pozwoliłyby na wywiązywanie się z zadań nałożonych na nią traktatami i innymi aktami prawnymi. A to oznacza konieczność pozyskiwania nowych zasobów własnych Unii Europejskiej. W ostatnich latach pojawiły się propozycje wprowadzania nowych zasobów własnych w postaci jednolitego podatku VAT, który obowiązywałby w jednakowym stopniu wszystkie państwa członkowskie oraz w postaci podatku od transakcji finansowych. Wadą nowej metodologii wyliczania zasobu własnego opartego na podatku VAT od dostaw towarów i usług, nabycia oraz importu podlegających podstawowej stawce VAT w każdym państwie członkowskim jest złożoność metodologii wyliczeń. Mimo poczynionych starań ww. podatki nadal nie będą typowym środkiem własnym, który wpływa bezpośrednio do budżetu Unii Europejskiej. Będą one przekazywane za pośrednictwem organów państwowych lub podmiotów gospodarczych w wypadku podatku od transakcji finansowych i nadal będą zależne od systemów oraz stawek podatkowych każdego państwa członkowskiego. Słowa kluczowe: dochody budżetu UE, nowe kategorie zasobów własnych, wspólny podatek od transakcji finansowych, unijny podatek VAT

\section{New sources of European Union's own resources}

\footnotetext{
Abstract

The mission of the European Community and later the European Union was to take all actions that reduce disparities in economic development among Member States
} 
and their regions. These objectives were achieved through creating a customs union, a single European market and economic and monetary union, and the introduction and implementation of trade, agricultural, cohesion, competition policies. The problem of obtaining financial resources that would allow the EU to fulfill the tasks assigned to it by treaties and other legal acts is inseparable from the functioning of the European Union. The EU needs to raise new own resources. In recent years there have been proposals for the introduction of new own resources in the form of a uniform VAT which would apply equally to all Member States and in the form of a tax on financial transactions. The principal disadvantage of the new methodology for calculating own resource based on VAT on supplies of goods and services, acquisitions and imports subject to the standard rate of VAT in each Member State is its complexity. Despite the efforts made, the abovementioned taxes still will not be typical own resource that directly supplies the budget of the European Union. They will still be transferred through state agencies or economic entities for tax on financial transactions and they will continue to be dependent on the systems and tax rates of each Member State.

Keywords: competences of the European Union, EU tax law, sovereignty, taxes

Powołane do życia w latach 50. Wspólnoty Europejskie, przekształcone później w Unię Europejską, miały podejmować wszelkie działania prowadzące do zmniejszenia różnic w rozwoju gospodarczym poszczególnych państw członkowskich oraz w ich regionach. Cele te były osiągane m.in. przez realizację polityki: handlowej, rolnej, spójności, konkurencji itp. Nierozłącznie z funkcjonowaniem Unii Europejskiej i urzeczywistnianiem jej celów wiąże się konieczność pozyskania środków finansowych, które pozwoliłyby na skuteczne wywiązywanie się z zadań nałożonych na nią traktatami i innymi aktami prawnymi. Celem artykułu jest przedstawienie problemu pozyskiwania nowych zasobów własnych Unii Europejskiej opartych na podatku VAT i podatku od transakcji finansowych. W artykule przedstawiono źródła pozyskiwania zasobów własnych Unii Europejskiej, propozycje zmian w naliczaniu podatku od wartości dodanej przez państwa członkowskie ujęte we wnioskach Komisji Europejskiej, różnice w wyliczaniu należnego podatku VAT według stosowania metody obecnej oraz proponowanej we wnioskach Komisji, a także wskazano obszary i działania z zakresu modernizacji zarządzania systemem VAT w państwach członkowskich.

\section{Unia Europejska jako organizacja międzynarodowa}

Unia Europejska do grudnia 2009 r. była kombinacją struktur ponadnarodowych oraz międzyrządowych. Jako organizacja międzynarodowa, posiadająca 
podmiotowość prawną, funkcjonuje od 1 grudnia 2009, tj. od czasu wejścia w życie traktatu lizbońskiego. Nie stanowi on żadnej nowej konstytucji, ale opiera się na Traktacie o Unii Europejskiej oraz Traktacie ustanawiającym Wspólnotę Europejską (zwanym obecnie Traktatem o funkcjonowaniu Unii Europejskiej). Traktat lizboński likwiduje dotychczasowy podział na Unię Europejską i Wspólnoty Europejskie, czyniąc z Unii Europejskiej jedyny podmiot prawny. Wśród ważnych zmian należy wymienić wzmocnienie działalności Unii na arenie międzynarodowej. Służyć temu ma powołanie urzędu ministra spraw zagranicznych UE, którego nazwano Wysokim Przedstawicielem do Spraw Zagranicznych i Polityki Bezpieczeństwa. Dysponuje on własną służbą dyplomatyczną, tzw. Europejską Służbą Działań Zewnętrznych ${ }^{1}$. Traktat wskazuje, które kompetencje przysługują Wspólnocie, tj.:

- w art. 3 TUE, m.in. wspieranie pokoju, wartości Unii i dobrobytu jej narodów, zagwarantowanie swoim obywatelom przestrzeni wolności, bezpieczeństwa i sprawiedliwości bez granic wewnętrznych, zagwarantowanie swobody przepływu osób, azylu, imigracji, zapobieganie i zwalczanie przestępczości, ustanowienie wspólnej waluty euro,

- w art. 4 TFUE - poszanowanie tożsamości narodów,

- w art. 5 TUE - stanowiącym o zasadzie pomocniczości i proporcjonalności w wykonywaniu kompetencji Unii oraz w których Unia Europejska podejmuje działania

- art. 3 TFUE - w zakresie unii celnej, wspólnej polityki handlowej, polityki pieniężnej wobec państw członkowskich, których walutą jest euro.

Ponadto w art. 2 ust. 5 TFUE wskazuje się na kompetencje wspierające i koordynujące Unii. Unia ma kompetencję w zakresie prowadzenia działań w celu wspierania, koordynowania lub uzupełniania działań państw członkowskich, nie zastępując ich kompetencji w tych dziedzinach ${ }^{2}$.

Integralną część traktatów stanowią tabele ekwiwalencyjne, protokoły i wyjaśnienia. Duże znaczenie dla unijnego porządku prawnego ma Karta praw podstawowych. Prawem wiążącym są też umowy międzynarodowe z państwami trzecimi (w tym układy stowarzyszeniowe), których stroną były Wspólnota Europejska i Unia Europejska. Dokończeniem dorobku prawnego Unii są akty prawa wtórnego powstałe na podstawie traktatów i umowy międzynarodowe.

Wśród teoretyków prawa, politologii i stosunków międzynarodowych trwa spór, jaką formą dokładnie jest Unia. Federaliści doszukują się w niej państwa federacyjnego

1 O. Barburska, D. Milczarek, Historia integracji europejskiej w zarysie, Centrum Europejskie Uniwersytetu Warszawskiego, Warszawa 2013, s. 165.

2 J. Barcz, Poznaj Traktat z Lizbony, UKIE, Warszawa 2008, s. 23-24. 
lub konfederacji. Zwolennicy koncepcji Europy ojczyzn wykazują, że jest to tylko współpraca między państwami, a więc bliższa jest ona organizacji międzynarodowej.

\section{System perspektyw finansowych jako procedura budżetowa}

W związku z zadaniami, które spoczywają na Unii Europejskiej jako organizacji międzynarodowej, konieczne jest pozyskanie środków oraz opracowanie planu finansowego (tzw. ram finansowych) na ich realizację. Prace nad ramami finansowymi, tak samo jak nad rocznym budżetem UE, dotyczą zarówno wydatków, jak i dochodów. Każde zaplanowane wydatki muszą mieć pokrycie w odpowiedniej kwocie środków finansowych, pozwalającej na realizację przez Unię Europejską celów, które są określane w perspektywie wieloletniej i realizowane za pomocą wielu działań podejmowanych zarówno na poziomie państw członkowskich, jak i przez UE 3 .

W latach 80. polityczna i instytucjonalna równowaga systemu finansowego Wspólnoty znalazła się pod rosnącą presją. Atmosfera konfliktu w stosunkach między obydwoma organami władzy budżetowej, tj. Parlamentem Europejskim i Radą, miała wpływ na funkcjonowanie rocznej procedury budżetowej, której stosowanie stawało się coraz trudniejsze i doprowadziło do nierównowagi budżetowej oraz coraz większej rozbieżności między wspólnotowymi zasobami a potrzebami. Z tego powodu Wspólnota ustanowiła system mający na celu usprawnienie funkcjonowania procedury budżetowej. Zawierając porozumienie międzyinstytucjonalne, Parlament Europejski, Rada i Komisja z góry uzgadniają główne priorytety budżetowe na kilka lat. W ramach tych priorytetów ustanowione zostały ramy wydatków wspólnotowych (tzw. wieloletnie ramy finansowe) w formie perspektywy finansowej. System perspektyw finansowych usprawnia tym samym funkcjonowanie procedury budżetowej i zapewnia przestrzeganie dyscypliny budżetowej. Wieloletnie ramy finansowe nie są wymienione w traktatach. Określają one kwotę maksymalną oraz strukturę prognozowanych wydatków Wspólnoty. Pierwsze porozumienie międzyinstytucjonalne zostało zawarte w 1988 r., aby ułatwić wdrożenie perspektywy finansowej na lata 1988-1992 (pakiet Delors I) i służyło zapewnieniu środków na budżetową realizację Jednolitego aktu europejskiego. Od tego czasu perspektywa finansowa była uaktualniana: w 1992 r. na lata 1993-1999 (pakiet Delors II), w 1999 r. na lata 2000-2006 (Agenda 2000), w 2006 na lata 2007-2013 i w 2013 na lata 2014-2020. System

3 E. Małuszyńska, M. Sapała, Wieloletnie ramy finansowe Unii Europejskiej na lata 2014-2020, „Studia Biura Analiz Sejmowych" 2012, nr 3(31), s. 111. 
perspektyw finansowych ma na celu zwiększenie przestrzegania dyscypliny budżetowej, kontrolowanie wzrostu wydatków i zapewnienie sprawnego funkcjonowania procedury budżetowej. W ramach wieloletnich ram finansowych wprowadzone są dwa pułapy: jeden dla wszystkich wydatków i jeden dla każdej kategorii wydatków. Dla każdego okresu objętego programem określone są w ramach finansowych pułapy (tzn. maksymalne kwoty na pokrycie zobowiązań i na pokrycie płatności) według działów (kategorii wydatków) dla każdego roku. W rocznej procedurze budżetowej określony jest natomiast dokładny poziom wydatków i ich podział między różne pozycje budżetu dla danego roku. Podział wydatków według działów opiera się na priorytetach politycznych Unii dla danego okresu. Odrębność poszczególnych działów oznacza, że dana pozycja budżetu finansowana jest w ramach określonego działu. Aby móc reagować w wypadku nieprzewidzianych wydatków, każdy dział musi dysponować wystarczającymi środkami w celu umożliwienia, jeżeli zajdzie taka potrzeba, ewentualnych przesunięć środków między działaniami w ramach tego samego działu. Margines na nieprzewidziane wydatki między pułapem zasobów własnych i pułapem środków na pokrycie płatności ma na celu:

- umożliwienie przystąpienia do zmiany ram finansowych, aby móc reagować w wypadku nieprzewidzianych przy określaniu perspektywy finansowej wydatków,

- złagodzenie skutków niższego niż przewidziano wzrostu gospodarczego. Jeżeli faktyczny DNB jest niższy niż przewidziano, pułap środków na płatności, który jest kwotą bezwzględną, może, przy wykorzystaniu marginesu, być finansowany z pułapu zasobów własnych wyrażonego w procentach PNB i nie może poza niego wykraczać.

Ogólny pułap środków na pokrycie zobowiązań otrzymuje się przez dodanie różnych pułapów dla poszczególnych działów. Aby sprawdzić zgodność perspektywy finansowej z pułapem zasobów własnych, stanowiącym bezwzględną granicę zasobów, które państwo członkowskie może udostępnić Unii, ustanowiony zostaje roczny pułap środków na pokrycie płatności. Pułap ten jest ogólny i nie jest podzielony według działów. Dodatkowo wyrażony jest jako procent szacowanego dochodu narodowego brutto (DNB) Wspólnoty. Postanowienia wykonawcze dotyczące wieloletnich ram finansowych określone są w porozumieniu międzyinstytucjonalnym, które zawiera zasady i procedury dotyczące corocznego zarządzania wieloletnimi ramami finansowymi (takie jak dostosowania techniczne, dostosowania związane z wykonywaniem lub mające na celu przygotowanie do rozszerzenia Unii oraz procedury zmiany ram finansowych). Pozwala to usprawnić funkcjonowanie rocznej procedury budżetowej. Każdego roku Komisja dokonuje, na własną odpowiedzialność, dopasowań technicznych ram finansowych na nadchodzący rok. Dopasowania te dotyczą następujących działań: 
- ponieważ ramy finansowe wyrażone są w cenach stałych, niezbędne jest każdego roku dopasowanie ich do inflacji, aby utrzymać pierwotną siłę nabywczą na poziomie pułapu każdego działu. Dopasowanie techniczne ma zwykle miejsce pod koniec roku n-2 dla danego roku n, na podstawie najnowszych danych i dostępnych prognoz gospodarczych. Dla danego roku nie są dokonywane żadne dalsze dostosowania techniczne,

- pułap zasobów własnych wyrażony jest jako procent DNB. Odzwierciedlenie tego pułapu jako wartości bezwzględnej oznacza, że dla celów dostosowania technicznego należy się oprzeć na najnowszych danych dotyczących DNB Unii. To w tych okolicznościach sprawdzana jest zgodność między całkowitymi środkami na pokrycie płatności i dostępnymi zasobami własnymi.

Komisja może również przedstawić obydwu organom władzy budżetowej wniosek dokonania dostosowań finansowych w dwóch następujących wypadkach:

- realokacji środków na pokrycie płatności dostępnych na rzecz działań strukturalnych w wypadku stwierdzonego opóźnienia w programowaniu takich działań,

- ponownego oszacowania potrzeb w ramach niektórych działów w związku z przystąpieniem nowych państw członkowskich.

Na wniosek Komisji obydwa organy władzy budżetowej mogą dokonać zmiany ram finansowych. Pozwoli to Wspólnocie podejmować działania, zgodnie z pułapem zasobów własnych, w wypadku wystąpienia okoliczności, których nie można było przewidzieć w momencie określania perspektywy finansowej .

\section{Źródła pozyskiwania zasobów własnych Unii Europejskiej}

Budżet ogólny Unii Europejskiej jest, bez uszczerbku dla innych dochodów, finansowany w całości z zasobów własnych Wspólnot. W decyzji Rady z dnia 7 czerwca 2007 r. w sprawie systemu zasobów własnych Wspólnot Europejskich ${ }^{5}$ wskazano źródła zasobów własnych. System zasobów własnych Wspólnot musi zapewniać odpowiednie środki na prowadzenie polityki w poszczególnych dziedzinach w sposób uporządkowany, przy uwzględnieniu potrzeby ścisłej dyscypliny budżetowej. Przy tym żadne państwo członkowskie nie może ponosić obciążenia budżetowego, które byłoby nadmierne w stosunku do jego względnej zamożności. Do celów ww. decyzji dochód narodowy brutto (DNB) definiuje się jako roczny DNB według cen rynkowych, podany przez Komisję w ramach stosowania Europejskiego

\footnotetext{
4 http://europa.eu/legislation_summaries/budget/134012_pl.htm, dostęp 24.08.2014.

5 2007/436/WE, Euratom, Dz. U. UE z 23.06.2007 r. L 163/17.
} 
systemu rachunków narodowych i regionalnych we Wspólnocie (tzw. „ESA”). W dniu 28 grudnia 2001 r. Komisja poinformowała Parlament Europejski i Radę o nowych pułapach. Pułap zasobów własnych wyznaczono wówczas na poziomie $1,24 \%$ łącznych DNB państw członkowskich według cen rynkowych, natomiast pułap środków na pokrycie zobowiązań określono na poziomie 1,31\% łącznych DNB państw członkowskich ${ }^{6}$.

Na zasoby własne zapisane w budżecie ogólnym Unii Europejskiej składają się dochody pochodzące z następujących źródeł:

a) z opłat, premii, kwot dodatkowych lub wyrównawczych, kwot lub czynników dodatkowych, ceł pobieranych na podstawie Wspólnej Taryfy Celnej i innych ceł, które zostały lub zostaną ustanowione przez instytucje Wspólnot w odniesieniu do handlu z państwami trzecimi, ceł na produkty objęte nieobowiązującym już Traktatem ustanawiającym Europejską Wspólnotę Węgla i Stali, a także wkładów i innych opłat przewidzianych w ramach wspólnej organizacji rynków cukru,

b) z wszelkich nowych obciążeń wprowadzonych w ramach wspólnej polityki, zgodnie z Traktatem WE lub Traktatem Euratom (stanowią one również zasoby własne zapisywane w budżecie ogólnym Unii Europejskiej),

c) z podatków i innych odliczeń od wynagrodzeń pracowników instytucji UE, odsetek bankowych, składek wpłacanych przez państwa spoza UE na niektóre programy, odsetek od zaległych płatności oraz grzywien ${ }^{8}$, stanowiących pozostałe dochody (ok. 1\%),

d) podatku VAT.

Państwa członkowskie UE zatrzymują 25\% pobranych kwot wymienionych w pkt a) tytułem kosztów poboru, tj. na pokrycie kosztów funkcjonowania administracji celnej. Zgodnie z decyzją Rady stosuje się stawkę jednolitą obowiązującą wszystkie państwa członkowskie w odniesieniu do zharmonizowanych podstaw VAT określonych zgodnie z zasadami wspólnotowymi. Podstawa brana pod uwage w tym celu nie może przekraczać 50\% DNB dla każdego państwa członkowskiego. Wysokość stawki jednolitej ustalono na poziomie 0,30\%. Wysokość tej stawki pozostaje aktualna również dla perspektywy finansowej na lata 2014-2020․ W kwestii podatku VAT decyzja Rady określa jednolitą stawkę poboru oraz wyjątki od niej przyjęte dla Austrii, Niemiec, Holandii i Szwecji, jak również zapisy dotyczące rabatu

6 Ibidem.

7 Art. 2 decyzji Rady z dnia 7 czerwca 2007 r. w sprawie systemu zasobów własnych Wspólnot Europejskich.

8 http://europa.eu/rapid/press-release_MEMO-13-1004_pl.htm, dostęp 26.08.2014.

9 W latach 2007-2013 stawkę poboru zasobów VAT dla Austrii ustalono na poziomie 0,225\%, dla Niemiec - na poziomie 0,15\%, a dla Holandii i Szwecji - na poziomie 0,10\%. 
brytyjskiego $^{10}$. Rabat brytyjski to porozumienie z Fontainebleau zawarte w 1984 r., które zapewniło Wielkiej Brytanii rabat związany z różnicą między udziałem tego państwa w płatnościach opartych na podatku VAT oraz jego udziałem w wydatkach Wspólnoty. Oznaczało to obniżenie brytyjskiej podstawy VAT, a koszty tego rabatu miały być finansowane przez wszystkie państwa członkowskie proporcjonalnie do ich wkładu z tytułu VAT, z wyjątkiem Niemiec, którym zagwarantowano redukcję stawki o jedną trzecią wobec brytyjskiej korekty. W rezultacie powstały trzy stawki procentowe VAT - obowiązujące odpowiednio dla Wielkiej Brytanii, Niemiec oraz pozostałych państw członkowskich. Miały to być środki przejściowe, ale w rzeczywistości zapisy te pozostają w mocy do dnia dzisiejszego ${ }^{11}$.

Cła są nakładane z tytułu przywozu towarów z państw trzecich (są pobierane jednolicie na podstawie Wspólnej Taryfy Celnej), a opłaty cukrowe są nakładane na producentów cukru i izoglukozy w ramach wspólnej organizacji rynku cukru. Opłaty te są pobierane od podmiotów gospodarczych (importerów) i zbierane przez państwa w imieniu UE, która jest unią celną. Każde państwo członkowskie przekazuje obecnie do budżetu UE trzy czwarte swoich dochodów z ceł oraz opłat rolnych ${ }^{12}$.

Dla wieloletnich ram finansowych (WRF) na lata 2014-2020 rozporządzeniem Rady (UE, Euratom) nr 1311/2013 z dnia 2 grudnia 2013 r. określającym wieloletnie ramy finansowe na lata 2014-202013 utrzymano pułap zasobów własnych w wysokości 1,24\% DNB, określony w decyzji Rady 2007/436/WE, Euratom. W każdym roku, w okresie objętym WRF, obowiązuje zasada, że wymagana łączna kwota środków na płatności, po rocznym dostosowaniu i z uwzględnieniem wszelkich innych dostosowań oraz rewizji, nie może skutkować taką stawką poboru zasobów własnych, która przekraczałaby pułap zasobów własnych określony zgodnie z decyzją 2007/436/WE, Euratom ${ }^{14}$. W WRF na lata 2014-2020 przyjęto poziom 1\% DNB na płatności i 1,05\% na zobowiązania.

${ }^{10}$ W perspektywie finansowej 2014-2020 Dania, Holandia i Szwecja będą korzystały z obniżki brutto swojego rocznego wkładu opartego na DNB w wysokości odpowiednio $130 \mathrm{mln}$ euro, $695 \mathrm{mln}$ euro i $185 \mathrm{mln}$ euro. Austria będzie korzystała z obniżki brutto swojego rocznego wkładu opartego na DNB w wysokości $30 \mathrm{mln}$ euro w 2014 r., $20 \mathrm{mln}$ euro w 2015 r. i $10 \mathrm{mln}$ euro w 2016 r.; obniżona stawka poboru VAT dla Niemiec, Holandii i Szwecji została ustalona na poziomie 0,15\%. Źródło: http://europa. eu/rapid/press-release_MEMO-13-1004_pl.htm, dostęp 26.08.2014.

${ }_{11}$ Parlament Europejski, dokument roboczy w sprawie zasobów własnych opartych na podatku od wartości dodanej, Komisja Budżetowa, 19.06.2012 r., PE491.364v01-00, s. 5-6.

${ }^{12}$ E. Kawecka-Wyrzykowska, VAT jako źródło dochodu budżetu europejskiego (VAT as an EU budget resource - a study prepared at the request of the Office for European Integration in Poland in the framework of consultations on the EU Budget Reform), Warszawa, styczeń 2008, s. 5.

${ }^{13}$ Dz. U. UE z 20.12.2013 r. L 347/884.

${ }^{14}$ Art. 4 rozporządzenia Rady (UE, Euratom) nr 1311/2013 z dnia 2 grudnia 2013 r. określającego wieloletnie ramy finansowe na lata 2014-2020. 


\section{Nowe zasady pozyskiwania zasobów własnych Unii Europejskiej}

Zasoby własne oparte na VAT zostały wprowadzone w $1970 \mathrm{r}$. jako potencjalnie rzeczywiste zasoby własne przy założeniu, iż ciągły proces harmonizacji prawa poszczególnych państw w zakresie VAT doprowadzi do pełnego zharmonizowania krajowych podstaw podatku od wartości dodanej. Jednakże 42 lata później, po przystąpieniu do UE kolejnych 21 państw członkowskich, obserwuje się tendencję odwrotną. Zasoby własne oparte na VAT stają się coraz bardziej złożone, a sposób ich obliczania coraz bardziej skomplikowany i coraz mniej zrozumiały. Jak wynika z obserwacji Parlamentu Europejskiego, to, co początkowo postrzegane było jako rzeczywiste zasoby własne oparte na VAT, obecnie przekształciło się w czysto statystyczne narzędzie, które faktycznie stanowi inną formę DNB i przekazywane jest $\mathrm{z}$ budżetów krajowych. Dnia 29 czerwca 2011 r. Komisja przedstawiła wnioski w sprawie nowych wieloletnich ram finansowych na lata 2014-2020 wraz z wnioskami w sprawie reformy systemu zasobów własnych Unii. Wnioski te obejmują również wniosek dotyczący decyzji w sprawie zasobów własnych VII (DZW), który wzywa do zniesienia obecnie obowiązującego systemu zasobów własnych opartych na VAT i zastąpienia go nowymi zasobami opartymi na nowym unijnym zasobie VAT, opierającymi się na uproszczonych i bardziej przejrzystych metodach obliczeniowych; nie zakłada jednak stworzenia nowego, paneuropejskiego podatku VAT ${ }^{15}$.

Istniejące ramy prawne regulujące kwestę podatku VAT jako zasobu własnego budżetu Unii Europejskiej regulowały następujące akty prawne:

1. Decyzja Rady w sprawie zasobów własnych nr 2007/436,

2. Rozporządzenie Rady (EWG, Euratom) nr 1553/89 z dnia 29 maja 1989 r. w sprawie ostatecznych jednolitych warunków poboru środków własnych pochodzących z podatku od wartości dodanej ${ }^{16}$.

Rozporządzenie Rady nr 1553/89 określa techniczne zasady ustalania podatku. Ponadto określa zasady dotyczące informowania Komisji przez państwa członkowskie o stosowanych przez nie procedurach rejestracji podatników, ustalania i poboru podatku VAT oraz o formach i wynikach systemów kontroli podatku VAT w państwach członkowskich. Na mocy tego rozporządzenia Komisja wraz z danym państwem członkowskim może rozważać, czy procedury stosowane w danym państwie

15 Parlament Europejski, dokument roboczy w sprawie zasobów własnych opartych na podatku od wartości dodanej, Komisja Budżetowa, 19.06.2012 r., PE491.364v01-00, s. 2.

16 Dz. U. L 155 z 7.6.1989, s. 9; ostatnio zmienione rozporządzeniem Rady (WE) nr 807/2003 z dnia 14 kwietnia $2003 \mathrm{r}$. 
członkowskim można ulepszyć z punktu widzenia poprawy ich skuteczności. W tym celu Komisja sporządza co trzy lata raport w sprawie procedur stosowanych w państwach członkowskich oraz rozważanych ulepszeń.

Traktat z Lizbony znacząco zmienił strukturę prawną UE w odniesieniu do zasobów własnych. Art. 311 TFUE stanowi, iż „bez uszczerbku dla innych dochodów budżet jest finansowany całkowicie z zasobów własnych” oraz że Rada może „ustanawiać nowe lub uchylać istniejące kategorie zasobów własnych". Ponadto Traktat stanowi, iż Rada może ustanowić środki wykonawcze w odniesieniu do systemu zasobów własnych Unii w zakresie zgodnym ze specjalną procedurą ustawodawczą i po uzyskaniu zgody Parlamentu Europejskiego. Natomiast Art. 322 ust. 2 TFUE zawiera przepisy określające sposoby i procedurę, zgodnie z którymi dochody budżetowe przewidziane w ramach systemu zasobów własnych Unii „są pozostawione do dyspozycji” Komisji. Na tej podstawie, wnioski Komisji związane z zasobami własnymi opartymi na VAT dotyczyły (patrz także rysunek 1):

A. Decyzji Rady w sprawie systemu zasobów własnych Unii Europejskiej ${ }^{17}$, w której przewidywano zniesienie z dniem 31 grudnia 2013 r. obecnie obowiązujących zasobów własnych opartych na VAT oraz stworzenie nowych zasobów opartych na unijnym VAT. Zaproponowano utrzymanie istniejących tradycyjnych zasobów własnych, zastosowanie jednolitej stawki do sumy DNB wszystkich państw członkowskich. Wprowadzenie dwóch nowych kategorii zasobów własnych:

- o podatek od transakcji finansowych (PTF) - jego udział nie przekracza stawek minimalnych określonych w dyrektywie $\mathrm{PTF}^{18}$;

- o nowe zasoby oparte na VAT - które nie przekraczają 2\% stawki podstawowej VAT w każdym państwie członkowskim.

Część podatków i stawki poboru zasobów własnych ustala się w rozporządzeniu Rady określającym środki wykonawcze. W nowej decyzji ustalono koszty poboru w wysokości 10\% w odniesieniu do zasobów tradycyjnych (w porównaniu z 25\% obecnie). Zaproponowano także zmianę pułapu zasobów własnych z 1,24\% na 1,23\% sumy DNB państw członkowskich według ceny rynkowej w wypadku płatności i 1,29\% sumy DNB państw członkowskich według ceny rynkowej w wypadku zobowiązań. Wniosek dotyczący decyzji Rady przewidywał także zniesienie rabatu brytyjskiego oraz innych istniejących rabatów oraz zastąpienie ich od stycznia 2014 r. nowym systemem kwot ryczałtowych w formie obniżenia rocznych wkładów opartych na DNB

17 Komisja Europejska, zmieniony wniosek Decyzja Rady w sprawie systemu zasobów własnych Unii Europejskiej, Bruksela, 9.11.2011, KOM(2011) 739 wersja ostateczna.

${ }_{18} \mathrm{Tj} .0,1 \% \mathrm{w}$ wypadku transakcji finansowych innych niezwiązanych z umowami dotyczącymi instrumentów pochodnych oraz $0,01 \% \mathrm{w}$ wypadku transakcji finansowych związanych $\mathrm{z}$ umowami dotyczącymi instrumentów pochodnych. 
- Niemcy (2500 mln EUR), Holandia (1500 mln EUR), Szwecja (350 mln EUR) i Wielka Brytania (3600 mln EUR) ${ }^{19}$.

B. Rozporządzenia Rady określającego środki wykonawcze dotyczące systemu zasobów własnych Unii Europejskiej, który określał udziały i stawki stosowane do zasobów własnych opartych na PTF i VAT, a mianowicie:

- VAT UE: 1,0\% wartości netto towarów lub usług podlegających podstawowej stawce VAT w każdym państwie członkowskim,

- PTF: jako część zasobów własnych służy dwóm trzecim minimalnych stawek określonych w dyrektywie PTF.

Rozporządzenie określa również metodę obliczania referencyjnego DNB i salda budżetowego. Zawiera wszystkie niezbędne przepisy dotyczące kontroli i nadzoru ${ }^{20}$.

C. Rozporządzenia Rady w sprawie metod i procedury udostępniania tradycyjnych zasobów własnych i zasobów własnych opartych na DNB oraz w sprawie środków w celu zaspokojenia potrzeb gotówkowych, które jest niezbędne do tego, aby określić metody, na podstawie których państwa członkowskie powinny obliczać te nowe zasoby, jak również procedury udostępniania ich budżetowi $\mathrm{UE}^{21}$. Wniosek miał na celu dopilnowanie, aby „potrzeby gotówkowe mogły być zaspokojone w ramach nowej struktury finansowania UE, przewidzianej we wniosku dotyczącym decyzji Rady w sprawie systemu zasobów własnych UE i w (odnośnych) nowych wnioskach”. W związku z tym, tekst określał procedury udostępniania przez państwa członkowskie VAT UE, tj.: reguły praktyczne dotyczące zasad księgowania i rozwiązań administracyjnych, terminów udostępniania zasobów własnych opartych na VAT (system miesięcznych sprawozdań), odsetek w razie opóźnień, jak również wnioskowano o ustanowienie procedury komitetowej (komitetu doradczego ds. zasobów własnych). Analiza obecnego systemu wskazuje, że w pierwszym kwartale roku systematycznie przyspiesza się przekazanie nawet dwóch dwunastych części zasobów własnych opartych na DNB i obecnych zasobów VAT, aby zaspokoić potrzeby gotówkowe, związane głównie z wydatkami z Europejskiego Funduszu Rolniczego Gwarancji (EFRG). Oczekuje się, że struktura finansowania UE ulegnie znacznym zmianom wraz z końcem obecnego systemu zasobów własnych opartych na VAT i wprowadzeniem nowej kategorii zasobów

19 Parlament Europejski, dokument roboczy nr $1 \mathrm{w}$ sprawie systemu zasobów własnych Unii Europejskiej Komisja Budżetowa, 01.12.2011 r., PE478.360v01-00, s. 5-6; zob. także Komisja Europejska, zmieniony wniosek Decyzja Rady w sprawie systemu zasobów własnych Unii Europejskiej, Bruksela, 9.11.2011, $\mathrm{KOM}(2011) 739$ wersja ostateczna.

${ }^{20}$ Parlament Europejski, dokument roboczy nr 1..., op.cit., s. 6; zob. także Komisja Europejska, zmieniony wniosek Rozporządzenie Rady określające środki wykonawcze dotyczące systemu zasobów własnych Unii Europejskiej, Bruksela, 9.11.2011, KOM(2011) 740 wersja ostateczna.

${ }^{21}$ Parlament Europejski, dokument roboczy w sprawie zasobów własnych..., op.cit., s. 3-4. 
własnych począwszy od 1 stycznia 2014 r. Szacowany udział zasobów własnych opartych na DNB i obecnych zasobów VAT w dochodach budżetu UE na 2012 r. wynosi 85\% (odpowiednio 74\% i 11\%). W 2020 r. obecny system zasobów własnych opartych na VAT przestanie istnieć, a udział zasobów własnych opartych na DNB spadnie do 40\%. To oznacza, że udział zasobów własnych opartych na regularnych wpływach finansowych, zdefiniowanych uprzednio w kontekście procedury budżetowej, zmniejszy się o połowę w porównaniu ze stanem obecnym. Podobnie wpływy pieniężne do budżetu UE z tytułu płatności zaliczkowych dwunastych części odnośnych zasobów własnych opartych na DNB odpowiadać będą połowie obecnych kwot, przy pozostałych czynnikach niezmienionych. Możliwość wezwania z wyprzedzeniem do przekazania innych zasobów własnych, w szczególności proponowanych nowych zasobów własnych opartych na VAT i PTF, wydaje się mniej praktyczna. Zasoby te będą oparte na faktycznych wpływach uzyskanych przez państwa członkowskie i wysokość kwot udostępnianych na potrzeby budżetu UE będzie się odpowiednio wahać. Zorganizowanie płatności dwunastych części wymagałoby mechanizmów przewidywania i odpowiednich zmian lub bilansów, co niepotrzebnie skomplikowałoby system. Ponieważ można założyć, że potrzeby gotówkowe przewyższać będą aktywa na rachunkach w pierwszym kwartale każdego roku, nawet po wezwaniu $\mathrm{z}$ wyprzedzeniem do przekazania dwóch dwunastych części opartych na DNB, proponuje się podwojenie (z dwóch do czterech) liczby dwunastych części udostępnianych $\mathrm{z}$ wyprzedzeniem w celu zrekompensowania zmniejszenia się udziału DNB w finansowaniu Unii ${ }^{22}$.

D. Dyrektywy Rady w sprawie wspólnego systemu podatku od transakcji finansowych. Celem wniosku jest stworzenie na szczeblu UE podatku od transakcji finansowych, który mógłby następnie w całości lub częściowo służyć jako zasoby własne w budżecie UE. Wniosek określał minimalne stawki PTF: 0,1\% w wypadku transakcji innych niż związane z umowami dotyczącymi instrumentów pochodnych oraz $0,01 \%$ w wypadku transakcji związanych z umowami dotyczącymi instrumentów pochodnych ${ }^{23}$. Dyrektywa odnosi się do wszelkich transakcji finansowych, takich jak zakup i sprzedaż instrumentów finansowych, np. akcje spółek, obligacje, instrumenty rynku walutowego, jednostki uczestnictwa w przedsiębiorstwach zbiorowego inwestowania, produkty strukturyzowane i pochodne oraz zawieranie lub zmiany umów dotyczących instrumentów pochodnych, pod warunkiem że przynajmniej

22 Parlament Europejski, dokument roboczy nr 1..., op.cit., s. 6; zob. także Komisja Europejska, zmieniony wniosek Rozporządzenie Rady w sprawie metod i procedury udostępniania tradycyjnych zasobów własnych i zasobów własnych opartych na DNB oraz w sprawie środków w celu zaspokojenia potrzeb gotówkowych, Bruksela, 9.11.2011, $\mathrm{KOM}(2011) 742$ wersja ostateczna.

${ }^{23}$ Parlament Europejski, dokument roboczy nr 1..., op.cit., s. 7. 
jedna strona transakcji została ustanowiona w państwie członkowskim oraz stroną transakcji jest instytucja finansowa (przedsiębiorstwa inwestycyjne, rynki zorganizowane, instytucje kredytowe, zakłady ubezpieczeń i reasekuracji, przedsiębiorstwa zbiorowego inwestowania oraz fundusze emerytalne i ich zarządzający, inne przedsiębiorstwa, których istotną część działalności finansowej stanowią transakcje) ustanowiona na terytorium państwa członkowskiego, działająca na własny rachunek lub na rachunek innej osoby, albo też działająca w imieniu strony transakcji. Z zakresu stosowania niniejszej dyrektywy wyłączone są następujące podmioty:

- Europejski Instrument Stabilności Finansowej,

- międzynarodowe instytucje finansowe utworzone przez co najmniej dwa państwa członkowskie, których celem jest mobilizacja środków i zapewnienie pomocy finansowej na rzecz swoich członków, którzy doświadczają poważnych problemów w zakresie finansowania lub są zagrożeni takimi problemami,

- partner centralny, oznaczający podmiot prawny, który pośredniczy pomiędzy kontrahentami w transakcji finansowej,

- krajowe i międzynarodowe centralne depozyty papierów wartościowych.

Niniejsza dyrektywa nie ma zastosowania w odniesieniu do następujących transakcji:

- na rynku pierwotnym, w szczególności w zakresie emisji akcji spółek oraz obligacji,

- w niektórych wypadkach transakcji z Unią Europejską, Europejską Wspólnotą Energii Atomowej, Europejskim Bankiem Centralnym, Europejskim Bankiem Inwestycyjnym, a także instytucjami ustanowionymi przez Unię Europejską lub Europejską Wspólnotę Energii Atomowej oraz innymi organizacjami lub instytucjami międzynarodowymi,

- transakcji z bankami centralnymi państw członkowskich.

PTF staje się wymagalny w wypadku każdej transakcji finansowej w momencie jej zaistnienia. Późniejsze anulowanie lub zmiana transakcji finansowej nie wpływają na wymagalność podatku, wyjąwszy zaistnienie pomyłki. W wypadku pozostałych transakcji, innych niż umowy dotyczące instrumentów pochodnych, podstawa opodatkowania PTF obejmuje wszystko, co stanowi zapłatę za przekazanie uiszczoną przez kontrahenta lub stronę trzecią czy należną od kontrahenta albo strony trzeciej. W wypadku transakcji związanych z umowami dotyczącymi instrumentów pochodnych podstawa opodatkowania dla celów PTF stanowi wartość nominalną umowy dotyczącej instrumentów pochodnych w momencie transakcji finansowej. Wartość nominalna jest bazową wartością nominalną zastosowaną do wyliczenia płatności dokonywanych z tytułu danej umowy dotyczącej instrumentów pochodnych. W wypadku kwoty wyrażonej w walucie obcej obowiązującym kursem wymiany będzie ostatni kurs sprzedaży odnotowany w momencie, gdy PTF staje się wymagalny 
na najbardziej reprezentatywnym rynku dewizowym danego państwa członkowskiego lub kurs wymiany ustalony przez odniesienie do tego rynku ${ }^{24}$.

E. Rozporządzenia Rady w sprawie metod i procedury udostępniania zasobów własnych opartych na podatku od transakcji finansowych. Wniosek określa metodę i procedury udostępniania przez państwa członkowskie zasobów własnych opartych na PTF na potrzeby budżetu UE. Tym samym określa zasady praktyczne dotyczące zasad księgowania i rozwiązań administracyjnych, terminów udostępniania zasobów własnych opartych na PTF (system miesięcznych sprawozdań), odsetek w razie opóźnień itp. Wnioskowano również o ustanowienie procedury komitetowej (komitetu doradczego ds. zasobów własnych), a przy tym przyznanie Komisji uprawnień wykonawczych, aby zapewnić jednolite warunki wykonania rozporządzenia ${ }^{25}$.

F. Rozporządzenia Rady w sprawie metod i procedury udostępniania zasobów własnych opartych na VAT. Rozporządzenie jest niezbędne do określenia metody, jaką państwa członkowskie powinny stosować do obliczania nowych zasobów oraz procedur ich udostępniania na potrzeby budżetu UE. W związku z tym określa nową metodę obliczeniową, a także - podobnie jak wniosek dotyczący rozporządzenia Rady w sprawie metod i procedury udostępniania zasobów własnych opartych na podatku od transakcji finansowych - tekst ten określa procedury udostępniania przez państwa członkowskie VAT UE: zasady praktyczne dotyczące zasad księgowania i rozwiązań administracyjnych, terminów udostępniania zasobów własnych opartych na VAT (system miesięcznych sprawozdań), odsetek w razie opóźnień, jak również wnioskuje się o ustanowienie procedury komitetowej (komitetu doradczego ds. zasobów własnych) ${ }^{26}$.

24 http://europa.eu/legislation_summaries/internal_market/single_market_services/financial_services_general_framework/mi0087_pl.htm, dostęp 26.08.2014.

${ }_{25}$ Parlament Europejski, dokument roboczy nr 1..., op.cit., s. 7; zob. także Komisja Europejska, zmieniony wniosek Rozporządzenie Rady w sprawie metod i procedury udostępniania zasobów własnych opartych na podatku od transakcji finansowych, Bruksela, 9.11.2011, KOM(2011) 738 wersja ostateczna.

${ }_{26}$ Parlament Europejski, dokument roboczy nr 1..., op.cit., s. 7; zob. także Komisja Europejska, zmieniony wniosek Rozporządzenie Rady w sprawie metod i procedury udostępniania zasobów własnych opartych na VAT, Bruksela, 9.11.2011, KOM(2011) 737 wersja ostateczna. 


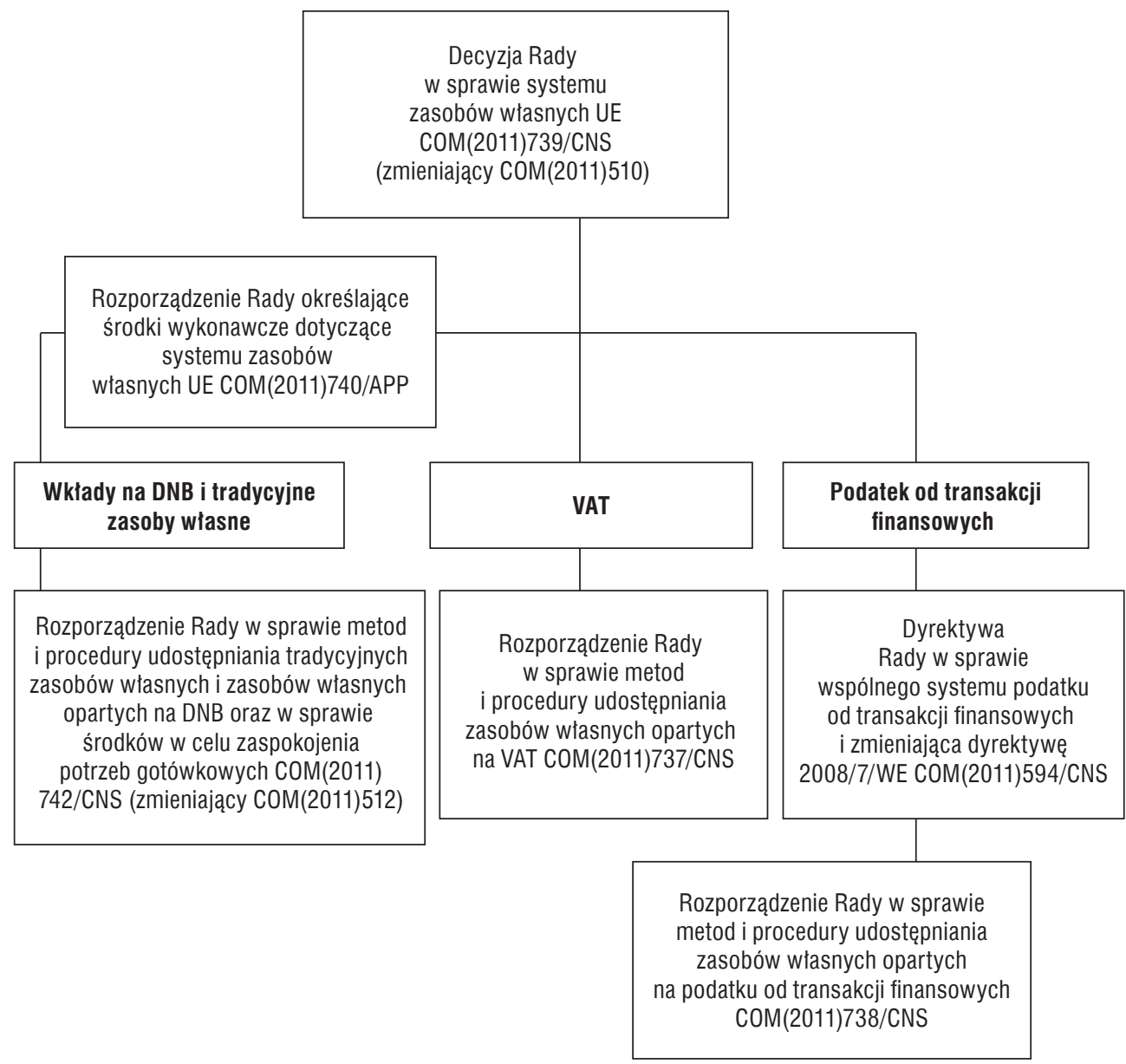

\section{Rysunek 1. Pakiet wniosków Komisji Europejskiej w sprawie zasobów własnych}

Źródło: Parlament Europejski, dokument roboczy nr 1 w sprawie systemu zasobów własnych Unii Europejskiej, Komisja Budżetowa, 01.12.2011 r., PE478.360v01-00, s. 3.

Proponowane zmiany miałyby zwiększyć wysokość zasobów własnych. Według szacunków przedstawionych w tabeli 1 nastąpiłby wzrost dochodów budżetu UE ze 131,1 mld euro uzyskanych według istniejącego systemu pozyskania środków własnych (dane z roku 2012 r.) do 162,7 mld euro w roku 2020. Wzrost ten wynikałby z włączenia do obecnego systemu pozyskiwania środków własnych podatku od transakcji finansowych oraz zharmonizowanego dla państw UE podatku VAT (tabela 1). 
Tabela 1. Zmiany w strukturze zasobów własnych

\begin{tabular}{|l|c|c|c|c|}
\hline \multirow{2}{*}{$\begin{array}{c}\text { Szacowany wpływ na strukture } \\
\text { zasobów własnych }\end{array}$} & \multicolumn{2}{|c|}{2012} & \multicolumn{2}{c|}{2020} \\
\cline { 2 - 5 } & Euro (mld) & $\begin{array}{c}\text { \% zasobów } \\
\text { własnych }\end{array}$ & Euro (mld) & $\begin{array}{c}\text { \% zasobów } \\
\text { własnych }\end{array}$ \\
\hline Tradycyjne zasoby własne & $\mathbf{1 9 , 3}$ & $\mathbf{1 4 , 7}$ & $\mathbf{3 0 , 7}$ & $\mathbf{1 8 , 9}$ \\
\hline $\begin{array}{l}\text { Istniejący wkład krajowy } \\
\text { Z czego: }\end{array}$ & $\mathbf{1 1 1 , 8}$ & $\mathbf{8 5 , 3}$ & $\mathbf{6 5 , 6}$ & $\mathbf{4 0 , 3}$ \\
- zasoby własne oparte na VAT & 14,5 & 11,1 & & \\
- zasoby własne oparte na DNB & 97,3 & 74,2 & 65,6 & 40,3 \\
\hline Nowe zasoby własne & & & $\mathbf{6 6 , 4}$ & $\mathbf{4 0 , 8}$ \\
Z czego: & & & 29,4 & 18,1 \\
- VAT UE & & & 37,0 & 22,7 \\
\hline - podatek od transakcji finansowych & & $\mathbf{1 0 0}$ & $\mathbf{1 6 2 , 7}$ & $\mathbf{1 0 0}$ \\
\hline Zasoby własne ogółem & $\mathbf{1 3 1 , 1}$ & & & \\
\hline
\end{tabular}

Źródło: Parlament Europejski, dokument roboczy nr 1 w sprawie systemu zasobów własnych Unii Europejskiej, Komisja Budżetowa, 01.12.2011 r., PE478.360v01-00, s. 4.

\section{Metody obliczania zasobu własnego opartego na VAT}

Z uwagi na złożoność problemu związanego z obliczaniem podatku VAT jako zasobu własnego przekazywanego przez państwo członkowskie do budżetu ogólnego UE, poniżej zaprezentowano metody liczenia tegoż zasobu własnego według metody obecnej oraz proponowanej w rozporządzeniu Rady w sprawie metod i procedury udostępniania zasobów własnych opartych na VAT (rozdział II). Obecnie obliczanie zasobu własnego opartego na podatku VAT składa się kilku etapów ${ }^{27}$ :

a) Obliczanie podstawy podatku:

Podatek należny

od podmiotów

zarejestrowanych jako

płatnicy VAT

Skorygowane wpływ

VAT
- Podatek naliczony, jaki zostanie zadeklarowany przez przedsiębiorstwa od zakupów i wydatków

Średnia ważona stawka VAT oparta na wszystkich stawkach VAT w danym państwie
$=$ Skorygowane wpływy VAT

= Podstawa pośrednia obliczenia podatku

27 Parlament Europejski, dokument roboczy w sprawie zasobów własnych..., op.cit., s. 7-8. 
b) Zharmonizowana podstawa opodatkowania

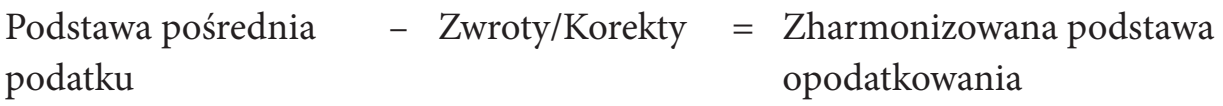

Tu należy mieć na uwadze to, że zharmonizowana podstawa VAT ograniczona jest w niektórych wypadkach pułapem na poziomie 50\% DNB każdego z państw członkowskich.

c) Wkład państw członkowskich w zasoby własne oparte na VAT

$\begin{array}{lll}\begin{array}{l}\text { Zharmonizowana } \\ \text { podstawa }\end{array} & \times \begin{array}{l}\text { Podstawowa stawka poboru } \\ \text { opodatkowania na poziomie } \\ 0,3 \% \text { (podlegająca wyjątkom) }\end{array} & \begin{array}{l}\text { Wpływy z tytułu } \\ \text { VAT do budżetu }\end{array}\end{array}$

Obecna metoda obliczania zasobu własnego opartego na podatku VAT nie jest zrozumiała dla przeciętnego obywatela, poza tym cechuje ją złożoność procesu obliczania wysokości składki w odniesieniu do podatku VAT uwzględniającego rabaty, których wysokości także podlegają zmianom. Jak stwierdził Trybunał Obrachunkowy w komunikacie Komisji pt. Reformowanie budżetu, zmienianie Europy, „nie jest możliwa pełna kontrola nad nim" ${ }^{28}$. Obecny system stanowi duże obciążenie finansowe dla państw członkowskich ze względu na utrzymanie administracji, która ma za zadanie zebranie odpowiednich danych, a następnie wykonanie obliczeń w celu uiszczenia składki do budżetu UE.

Nowe zasoby własne oparte na unijnym podatku VAT bazują na udziale podatku VAT od dostaw towarów i usług, nabycia i importu „podlegających podstawowej stawce VAT w każdym państwie członkowskim”. Przyjęcie tego systemu oznaczałoby przejście z teoretycznej koncepcji obecnego VAT obliczanego na podstawie statystyk do faktycznej harmonizacji, która już istnieje w UE w wypadku tych towarów i usług ze stawką podstawową. Co więcej, nowy system przeniesie ciężar większości czynności obliczeniowych obecnie wykonywanych przez państwa członkowskie na Komisję Europejską ${ }^{29}$.

Podatek VAT obliczany byłby w następujących etapach:

a) Obliczanie skorygowanych wpływów z podatku VAT

Rzeczywiste

wpływy za dany

miesiąc
- Korekta w niektórych państwach członkowskich
$=$ Skorygowane wpływy VAT

28 Ibidem, s. 9.

29 Ibidem, s. 10. 
b) Obliczanie średniego udziału wpływów z podatku VAT

Skorygowane $\times$ Jednolita stawka $=$ Średni udział wpływów wpływy VAT procentowa $\quad$ z podatku VAT pochodzących z objętych stawką podstawową dostaw na rzecz spożycia ${ }^{30}$

c) Obliczanie stawki podstawowej opartej na VAT

\begin{tabular}{|c|c|}
\hline $\begin{array}{l}\text { Średni udział wpływów } \\
\text { z podatku VAT } \\
\text { pochodzących z objętych } \\
\text { stawką podstawową } \\
\text { dostaw na rzecz spożycia }\end{array}$ & $\begin{array}{l}\times \text { Wartość stawki } \\
\text { podstawowej VAT } \\
\text { państwa członkowskiego } \\
(\text { wyrażona } \mathrm{w} \%)\end{array}$ \\
\hline
\end{tabular}

d) Obliczanie miesięcznej składki zasobów własnych opartej na podatku VAT $\begin{array}{lll}\begin{array}{l}\text { Podstawa zasobów } \\ \text { własnych opartych }\end{array} & \times \begin{array}{l}\text { Stawka procentowa } \\ \text { wg rozporządzenia } \\ \text { na VAT }\end{array} & \text { Miesięczna składka } \\ & \text { wykonawczego Rady członkowskich }\end{array}$

Stawka procentowa przedstawiona w rozporządzeniu wykonawczym Rady w sprawie zasobów własnych będzie stosowana do aktualnej wartości podstawy zasobów własnych opartych na VAT (stawka maksymalna $2 \%$ jest przedstawiona w decyzji Rady dotyczącej zasobów własnych, a stawka operacyjna 1\% w rozporządzeniu wykonawczym) $)^{32}$.

Wśród korzyści nowej metody liczenia zasobów własnych opartych na VAT wymienia się m.in.:

- większą przejrzystość, gdyż podstawę obliczenia będą stanowiły jedynie towary i usługi objęte podstawową stawką VAT we wszystkich państwach członkowskich oraz rzeczywiste dochody uzyskane przez państwa,

- mniej możliwości korekt podstawy VAT dla niektórych państw członkowskich (jedynie grzywny i kary, zwroty podmiotom niepodlegającym obowiązkowi podatkowemu, wpływy z terytoriów spoza UE, rozliczenie mnogich stawek podstawowych) w porównaniu z obecnie istniejącymi 22 kompensatami,

${ }^{30} \mathrm{Tj}$. dostaw na rzecz gospodarstw domowych lub innych podmiotów nieuprawnionych do odliczenia naliczonego podatku VAT. We wniosku Komisji zawarto propozycję, że stawka ta będzie obliczana na podstawie poważnych analiz statystycznych przeprowadzonych przez Komisję w ścisłej współpracy z państwami członkowskimi i zostanie ustalona na cały okres wieloletnich ram finansowych.

${ }^{31}$ Szacuje się, że powinna to być stawka procentowa zawierająca się między $15 \%$ a $27 \%$.

32 Parlament Europejski, dokument roboczy w sprawie zasobów własnych..., op.cit., s. 12. 
- fakt, że podstawę obliczenia będą stanowily jedynie towary i usługi objęte podstawową stawką VAT; jednakowe traktowanie wszystkich państw członkowskich UE - będzie istniała jednolita stawka procentowa mająca zastosowanie dla wszystkich państw członkowskich, w przeciwieństwie do obecnie obowiązujących różnych stawek,

- skupienie się na istotności - nowe zasoby będą opierały się na faktycznych przychodach, a nie na statystykach,

- niestosowanie żadnych pułapów,

- większa elastyczność systemu i możliwość dostosowania go do wszelkich przyszłych reform systemu podatkowego VAT bez konieczności wprowadzania zmian do obecnego wniosku w sprawie zasobów własnych ${ }^{33}$.

Do wad można zaliczyć trudną metodologię wyliczeń. Nadal przebiegają one w kilku etapach, są dość skomplikowane i wymagają przeprowadzenia złożonych obliczeń. Zwiększyło się obciążenie Komisji czynnościami administracyjnymi. Nowy podatek VAT w dalszym ciągu nie będzie stanowił zasobów własnych wpływających bezpośrednio do budżetu UE, będzie natomiast częścią dochodów uzyskanych z tytułu podatku VAT przez państwo członkowskie ${ }^{34}$.

\section{Obszary i działania z zakresu modernizacji zarządzania systemem VAT w państwach członkowskich}

Rozporządzenie 1553/891 w sprawie ostatecznych jednolitych warunków poboru środków własnych pochodzących z podatku od wartości dodanej nakłada na Komisję obowiązek przedkładania co trzy lata Parlamentowi Europejskiemu i Radzie sprawozdania w sprawie stosowanych w państwach członkowskich procedur dotyczących rejestracji podatników oraz ustalania i poboru podatku VAT, jak również na temat zasad i rezultatów działania ich systemów kontroli w zakresie VAT. Od roku $1989 \mathrm{r}$. przedłożono siedem sprawozdań, ostatnie - siódme w dniu 12.02.2014 r. Sformułowano w nim wnioski z przeprowadzonych kontroli od 2011 r., w których stwierdzono konieczność modernizacji zarządzania systemem VAT w państwach członkowskich. Od początku recesji i kryzysu finansowego w 2008 r. rośnie ubytek dochodów z tytułu VAT, którego wysokość w 2011 r. szacowano na około 1,5\% PKB UE-26. Występują jednak znaczne różnice pod względem ubytku dochodów z tytułu VAT w poszczególnych państwach członkowskich. W szczególności państwa, które dotkliwiej odczuły

\footnotetext{
33 Ibidem, s. 13.

34 Ibidem.
} 
skutki kryzysu, zmagają się z większym ubytkiem dochodów z tytułu VAT i nie zdołały w znaczny sposób poprawić swojej sytuacji w dłuższym okresie. Ponieważ ubytek dochodów z tytułu VAT jest jednym ze wskaźników wydajności i skuteczności zarządzania systemem VAT, państwa członkowskie będą musiały zmodernizować zarządzanie tym systemem w celu ograniczenia wspominanego ubytku dochodów. Rozwiązanie to jest istotne nie tylko z punktu widzenia dochodów i zasobów własnych z tytułu VAT, lecz także z punktu widzenia przedsiębiorstw i rządów w zakresie kosztów administracyjnych. Modernizacja zarządzania systemem VAT jest niezbędna i nieunikniona w wypadku tych państw członkowskich, które najdotkliwiej odczuły kryzys finansowy i doświadczają trudności w eliminacji deficytu budżetowego. Modernizacja może przynieść znaczne korzyści takim państwom członkowskim, jeżeli będą one skłonne do zmiany utrwalonych praktyk administracyjnych i udoskonalenia swoich postępowań administracyjnych ${ }^{35}$.

Działania, które mają podjąć państwa członkowskie zostały podsumowane poniżej według obszarów tematycznych:

a) Identyfikacji, rejestracji i wyrejestrowania podatnika VAT - państwa członkowskie muszą poprawić jakość informacji dostępnych w językach obcych dotyczących wymogów i procesu rejestracji podatnika VAT. Jednocześnie państwa członkowskie muszą również (dalej) opracować kompleksowy proces rejestracji, szczególnie wdrażając programy monitorowania przedsiębiorców obarczonych ryzykiem realizowane po rejestracji oraz przyspieszone procesy wyrejestrowania „znikających podmiotów gospodarczych”. Polski nie ma wśród państw, do których skierowano wnioski.

b) Procedury celnej 42 - państwa członkowskie powinny dopilnować, aby systematycznie sprawdzano numery identyfikacyjne VAT (zarówno importerów, jak i klientów) oraz aby wszystkie informacje dotyczące transakcji przekazywano krajowej administracji podatkowej. Niniejsze wnioski zostały skierowane także do Polski. Ponadto, Polska oraz inne państwa członkowskie są zobowiązane do uwzględnienia procedury celnej jako dodatkowego ryzyka w krajowych systemach analizy ryzyka oraz zintensyfikowania wymiany informacji dotyczących nielegalnych transakcji i nieuczciwych podmiotów gospodarczych, m.in. aktywnie wymieniając informacje za pośrednictwem sieci Eurofisc. Także wskazano, że około połowa państw członkowskich mogłaby rozważyć stosowanie licencji lub gwarancji wobec przedsiębiorców obarczonych ryzykiem w celu zapobiegania nadużyciom.

${ }^{35}$ Komisja Europejska, Sprawozdanie Komisji dla Rady i Parlamentu Europejskiego. Siódme sprawozdanie zgodne z art. 12 rozporządzenia (EWG, Euratom) nr 1553/89 o poborze podatku od wartości dodanej i procedurach kontrolnych, 12.02.2014 r., $\mathrm{KOM(2014)} 69$ wersja ostateczna, s. 13. 
c) Składania deklaracji VAT i dokonywania płatności VAT - większość państw członkowskich (w tym Polska) nadal musi wdrożyć systematyczne podejście do monitorowania opóźnień w składaniu deklaracji i dokonywaniu płatności VAT oraz przypadków niezłożenia deklaracji i niedokonania płatności VAT. Takie podejście obejmuje automatyczne procesy, np. automatyczne przypomnienia i natychmiastowe oszacowanie w wypadku braku złożenia deklaracji. Ponadto państwom członkowskim zdecydowanie zaleca się zbadanie wydajności ich systemów odsetek i kar w odniesieniu do opóźnień w składaniu deklaracji oraz dokonywaniu płatności VAT, a także nieskładania deklaracji i niedokonywania płatności VAT.

d) Poboru i odzyskiwania VAT - zasadniczo połowa państw członkowskich (bez Polski) musi wdrożyć procedury dokonywania odpisów długów, w wypadku których dowiedziono, że nie są ściągalne po rozsądnym koszcie. Bez programu bieżących odpisów administracja podatkowa ryzykuje marnowanie cennych zasobów na windykację nieściągalnych kwot. Ponadto państwa członkowskie - w tym także Polska - powinny opracować niesekwencyjne zintegrowane procesy windykacji należności.

e) Kontroli i dochodzenia w zakresie VAT - zalecenia obejmują z jednej strony zniesienie obowiązkowych kontroli określonych podatników przez wszystkie lata, a z drugiej zastosowanie systemu opartego na analizie ryzyka. Ten wniosek dotyczy także Polski.

f) Systemu rozstrzygania sporów podatkowych - wiele państw członkowskich powinno rozważyć wdrożenie obowiązkowej, niezależnej administracyjnej procedury rozstrzygania sporów, w ramach której sporne kwoty pozostają w pełni lub częściowo ściągalne podczas postępowania odwoławczego (bez Polski).

g) Przestrzegania przepisów dotyczących podatku VAT - państwa członkowskie muszą (w dalszym stopniu) opracować i wdrożyć strategie zarządzania ryzykiem braku zgodności oraz dokonywać oceny wyników wdrożonych środków w celu określenia najlepszych strategii wpływających na zachowanie podatników, tak aby dobrowolnie wywiązywali się oni ze swoich zobowiązań podatkowych. Wniosek dotyczy także Polski ${ }^{36}$.

$$
* * *
$$

W artykule przedstawiono, w ostatnim czasie szeroko dyskutowany, problem pozyskiwania nowych zasobów własnych Unii Europejskiej w postaci jednolitego podatku VAT, który obowiązywałby w jednakowym stopniu wszystkie państwa

36 Ibidem, s. 14-15. 
członkowskie oraz w postaci podatku od transakcji finansowych. Mimo poczynionych starań, podatki te nie będą typowym środkiem własnym, który wpływa bezpośrednio do budżetu Unii Europejskiej, ponieważ będą one przekazywane za pośrednictwem organów państwowych lub podmiotów gospodarczych w wypadku podatku od transakcji finansowych i nadal będą one zależne od systemów i stawek podatkowych każdego państwa członkowskiego. Wysokość podatku VAT wpłacanego do budżetu ogólnego Unii Europejskiej jest zatem mocno uzależniona od systemu podatkowego danego państwa członkowskiego oraz prowadzonej w nim polityki fiskalnej i polityki budżetowej. I odwrotnie, systemy podatkowe państw członkowskich są uzależnione od sytuacji budżetowej Unii Europejskiej. Komisja bowiem co trzy lata dokonuje przeglądu efektywności tego systemu i formułuje wnioski, które państwa członkowskie powinny realizować, właśnie w celu poprawy sytuacji finansowej budżetu Unii Europejskiej oraz w celu umożliwienia prowadzenia przez nią polityki publicznej. Niewątpliwie w obecnych realiach społeczno-gospodarczych istnieje konieczność poszukiwania nowych źródeł pozyskiwania środków do budżetu ogólnego Unii Europejskiej. Dla państw członkowskich istotne jest także to, aby źródła ich pozyskiwania nie były obciążeniem dla ich finansów publicznych. Dotyczy to zwłaszcza państw członkowskich mających problemy ze stabilnością własnego systemu finansów publicznych, które są objęte np. procedurami nadmiernego deficytu. System pozyskiwania środków z VAT jest oparty na dochodach budżetowych państwa członkowskiego, co oznacza, że część z wpływów z tytułu podatku VAT jest przetransferowywana na rzecz budżetu ogólnego UE, bądź ma pozostać do dyspozycji Komisji Europejskiej. To powoduje pewien uszczerbek $\mathrm{w}$ dochodach budżetowych państwa, co z kolei wpływa na możliwość realizacji bieżących zadań państwa wobec jego obywateli. Konieczność wygospodarowania dodatkowych wpływów może w rzeczywistości powodować zacieśnienie fiskalne w państwach członkowskich w celu zwiększenia bazy podatkowej i tym samym zwiększenia dochodów budżetowych lub może prowadzić do zadłużenia państwa członkowskiego, co bezpośrednio może wpłynąć na wysokość zadłużenia i stan finansów publicznych. Jest to bardzo istotne $\mathrm{z}$ tego powodu, że należy pamiętać o stosowaniu przez państwa członkowskie odpowiednich procedur budżetowych (regulacje ustanowione w tzw. sześciopaku), stabilizujących finanse publiczne. W rezultacie, w długim okresie, może dojść do pewnego paradoksu, zamiast rozwoju gospodarczego państwa może pojawić się stagnacja, zamiast oczekiwanego zrównoważonego rozwoju Unii Europejskiej - zastój, recesja. 


\section{Bibliografia}

Barburska O., Milczarek D., Historia integracji europejskiej w zarysie, Centrum Europejskie Uniwersytetu Warszawskiego, Warszawa 2013.

Barcz J., Poznaj Traktat z Lizbony, UKIE, Warszawa 2008.

Decyzja Rady z dnia 7 czerwca 2007 r. w sprawie systemu zasobów własnych Wspólnot Europejskich 2007/436/WE, Euratom, Dz. U. UE z 23.06.2007 r. L 163/17.

http://europa.eu/legislation_summaries/budget/134012_pl.htm, dostęp 24.08.2014.

http://europa.eu/legislation_summaries/internal_market/single_market_services/financial_services_general_framework/mi0087_pl.htm, dostęp 26.08.2014.

http://europa.eu/rapid/press-release_MEMO-13-1004_pl.htm, dostęp 26.08.2014.

Kawecka-Wyrzykowska E., VAT jako źródło dochodu budżetu europejskiego (VAT as an EU budget resource - a study prepared at the request of the Office for European Integration in Poland in the framework of consultations on the EU Budget Reform), Warszawa styczen 2008.

Komisja Europejska, zmieniony wniosek Decyzja Rady w sprawie systemu zasobów własnych Unii Europejskiej, Bruksela, 9.11.2011, KOM(2011) 739 wersja ostateczna.

Komisja Europejska, zmieniony wniosek Rozporządzenie Rady określające środki wykonawcze dotyczące systemu zasobów własnych Unii Europejskiej, Bruksela, 9.11.2011, KOM(2011) 740 wersja ostateczna.

Komisja Europejska, zmieniony wniosek Rozporządzenie Rady w sprawie metod i procedury udostępniania tradycyjnych zasobów własnych i zasobów własnych opartych na DNB oraz w sprawie środków w celu zaspokojenia potrzeb gotówkowych, Bruksela, 9.11.2011, $\operatorname{KOM}(2011) 742$ wersja ostateczna.

Komisja Europejska, zmieniony wniosek Rozporządzenie Rady w sprawie metod i procedury udostępniania zasobów własnych opartych na podatku od transakcji finansowych, Bruksela, 9.11.2011, $\mathrm{KOM}(2011) 738$ wersja ostateczna.

Komisja Europejska, zmieniony wniosek Rozporządzenie Rady w sprawie metod i procedury udostępniania zasobów własnych opartych na VAT, Bruksela, 9.11.2011, KOM (2011) 737 wersja ostateczna.

Komisja Europejska, Sprawozdanie Komisji dla Rady i Parlamentu Europejskiego Siódme sprawozdanie zgodne z art. 12 rozporządzenia (EWG, Euratom) nr 1553/89 o poborze podatku od wartości dodanej i procedurach kontrolnych, 12.02.2014 r., KOM(2014) 69 wersja ostateczna.

Małuszyńska E., Sapała M., Wieloletnie ramy finansowe Unii Europejskiej na lata 2014-2020, „Studia Biura Analiz Sejmowych” 2012, nr 3 (31).

Parlament Europejski, dokument roboczy nr $1 \mathrm{w}$ sprawie systemu zasobów własnych Unii Europejskiej, Komisja Budżetowa, 01.12.2011 r., PE478.360v01-00.

Parlament Europejski, dokument roboczy w sprawie zasobów własnych opartych na podatku od wartości dodanej, Komisja Budżetowa, 19.06.2012 r., PE491.364v01-00. 
Rozporządzenie Rady (EWG, Euratom) nr 1553/89 z dnia 29 maja 1989 r. w sprawie ostatecznych jednolitych warunków poboru środków własnych pochodzących z podatku od wartości dodanej Dz. U. L 155 z 7.6.1989, str. 9; ostatnio zmienione rozporządzeniem Rady (WE) nr 807/2003 z dnia 14 kwietnia 2003 r.

Rozporządzenie Rady (UE, Euratom) nr 1311/2013 z dnia 2 grudnia 2013 r. określającym wieloletnie ramy finansowe na lata 2014-2020, Dz. U. UE z 20.12.2013 r. L 347/884. 